DOI https://doi.org/10.18551/rjoas.2018-01.15

\title{
GENDER, RELIGIOSITY, POSITIVE MOOD AND WHISTLEBLOWING INTENTION
}

\author{
Dananjaya Dewa Gede Yudha*, Mawardi Rizal \\ Department of Accounting, Faculty of Economics and Business, Airlangga University, \\ Surabaya, Indonesia \\ *E-mail: yudha.dananjaya@yahoo.com
}

\begin{abstract}
The purpose of this study is to prove the relationship of gender, religiosity to whistleblowing intention with positive mood as a moderating variable. The sample of this research is accounting of 41 students after the purposive sampling. Data analysis technique used is correlation test. The results of study provide evidence of gender relationship to whistleblowing intentions; religiosity has no relationship to whistleblowing intentions and positive mood is able to moderate the relationship between gender and whistleblowing intentions.
\end{abstract}

\section{KEY WORDS}

Whistleblowing, intention, gender, religiosity, mood.

Whistleblowing has gained global attention and popularity over the last two decades of this case centered on the disclosure of unethical or illegal behavior, employers or officials at work by employees to third parties (Johnson, 2003). Jeon, (2017) reveals that whistleblowers play an important role in opening unethical behavior in government and making government more transparent and accountable to the public. Sweeney, (2008) states that wistleblowing is more effectively applied to reduce fraud than internal audit, external audit, or internal controlling system. Whistleblowing action has been recognized as a control mechanism to prevent unethical behavior, and to protect the organization's long-term prosperity and to ensure good corporate governance (Eaton \& Akers, 2007).

Some related fraud cased still exist quite a lot within an organization, it should be investigated about whistleblowing into an instrument to reveal it. Cunningham \& Harris, (2006) one of the cases revealed was the case of the Enron company. Enron Board has conducted a variety of fraud in the form of accounting manipulation. The case was revealed by the action whistleblowing is the case of British Telecom. Fraud in British Telecom affects its public accountant. At this moment, affected by Price Waterhouse Coopers (PwC) which is a reputable public accounting firm in the world and includes the bigfour. This accounting fraud failed to be detected by $\mathrm{PwC}$, it is precisely this fraud were detected by the reporting complaints (whistleblower), followed by a forensic accounting by KPMG. Fraud Accounting by British Telecom in Italy is actually relatively simple but the PWC auditor failed to detect it. Examples case involving whistleblowing that happened in Indonesia is Agus Condro in Bank Indonesia senior deputy elections and yohanes wowuruntu in case of system administration law bodies (Semendawai, et al., 2011).

Research on whistleblowing has been done using gender variables, religiosity and positive mood. Gender as variable is reused because there are inconsistencies in previous research. Regarding the variable religiosity, the measurements used by the researcher are Santa Clara Strength of Religious Faith (SCSORF) this can be said to be unique, because it adopts the si developed by (Plante \& Boccaccini, 1997). This measurement has not been used for research in Indonesia, and the reasons behind the Santa Clara Strength of Religious Faith (SCSORF) do not contain any reference to a particular religious orientation, and are suitable for it class of people from all affiliates or groups to religion. Related variables Positive Mood This variable has not been used in Indonesia so it becomes unique to use. Researchers using this positive mood as a derivative refers to the study of Zhang et al, (2009) using a positive mood as moderation. The importance of whistleblowing action, especially to expose cheating, motivates me to do research related to this whistleblowing 
intention. Here is my basic reason for researching this topic and the reasons for using variables.

Prosocial Behavior Theory. Brief \& Motowidlo (1986) describes prosocial behavioral theories as members' behavior in organizations to address individuals, groups, or organizations in which they interact and adhere to organizational rules and are conducted with the intention of improving the well-being of individuals, groups, or organizations. Dozier \& Miceli, (1986) whistleblowing is a form of prosocial behavior related to selfish and altruistic behavior. In other words, whistleblowing action is not entirely an altruistic act because it is also aimed at achieving personal gain. Prosocial behavior is a theory that supports the occurrence of whistleblowing. Whistleblowing is one of 13 forms of prosocial behavior (Brief \& Motowidlo, 1986). In line with Dozier \& Miceli (1985), whistleblowing behavior can be provided benefits to the organization or others while also benefiting the whistleblower itself so that whistleblowing can be regarded as prosocial behavior. Prosocial behavior can be used to describe individual ethical decision-making associated with intent to conduct whistleblowing.

Miceli et al, (1991) suggests tendency that more high from man for do whistleblowing. Lacayo \& Ripley, (2003); Street, (1995) shows more men tend to do whistleblowing rather than woman. Dworkin \& Baucus, (1998); Sims \& Keenan, (1998) found that women are less likely than men to engage in whistleblowing because men tend to occupy high position and status than women in the orgaization. Status characteristics theory argue that those with higher status have more opportunities to contribute to group tasks, receive more positive evaluations and exert greater influence (Carli \& Eagly, 1999).

$\mathrm{H}_{1}$ : A person who is sexually man will tend to have higher whistleblowing intentions than a woman who is gendered.

Planned Bahaviour Theory. Planned Behavior Theory is a theory in psychology that explained by Ajzen, (1991). This theory connects faith with behavior. This theory say how an interest in behavior and behavior can be formed. Interest in behavior is defined as an indication of individual readiness to display behavior, or it can be assumed to be a precursor to action. Actions can be interpreted as visible responses from individuals with respect to given targets. Ajzen, (1991) formulated three behavior-forming predictors. The first is attitude toward the behavior, is a positive or negative evaluation of individual about the performance of self in certain behavior. Second, subjective norms, are individual perceptions of certain behaviors that are influenced by significant other judgments. Third, the perception of behavior control (perceived behavioral control), is the ease or difficulty to perform certain behaviors.

Individual more religiously comply with the law and will do whistleblowing whenever they are confronted with unethical behavior in the workplace (Rokeach, 1969; Fernando, 2006) suggests religious individuals behave in accordance with the values inherent in the religion and will not confront undeserved behavior, it is possible to conduct whistleblowing at any time in an unethical situation that is very high. But some studies have found that there are individuals who see violations in the workplace, but chose not to report to the employer or institution that has the proper authority may be because of persecution or torture and sometimes cancellations made by the public related to whistleblowing (Dyck et al, 2010).

$\mathrm{H}_{2}$ : Someone who is religious will have more intention to do whistleblowing.

Social Learning Theory. Bandura (1986), Social Learning Theory argues that one would foresee the possible consequences of their own actions by observing the consequences experienced by others. Positive mood will tend to increase observer's expectation of positive results because people with positive moods may be a little worried. Thus a person in a positive mood will be more likely to be involved in whistleblowing because they will receive less worry about the risks or consequences they will receive.

Rest (1986), suggests that within the decision-making process, moods can affect the anticipation of the individual future consequences and may increase or decrease the likelihood of turning ethical judgments into action. Social psychology studies show that when people are in the PM (positive mood), they are more tend to help people, protect their organizations, and make constructive suggestions for organizations (George, 1991; Van 
Scotter \& Motowidlo, 1996). The role of PM (positive mood) in helping behavior implies that people with PM (positive mood) are more morally, more empathetic, and pay more attention to the welfare of others. Therefore, when someone positive mood must to make moral decisions about what is right or wrong.

$\mathrm{H}_{3}$ : Positive mood can moderate the gender relationship to whistleblowing intentions.

\section{METHODS OF RESEARCH}

This study uses a quantitative approach in the form of associative. Quantitative research is a research that emphasizes theoretical testing through measurement of research variables with numbers and data analyzed using statistics procedures (Indriantoro \& Supomo, 2013). Research in the form of associative is research that aims to determine the relationship between two variables or more (Sugiyono, 2013).

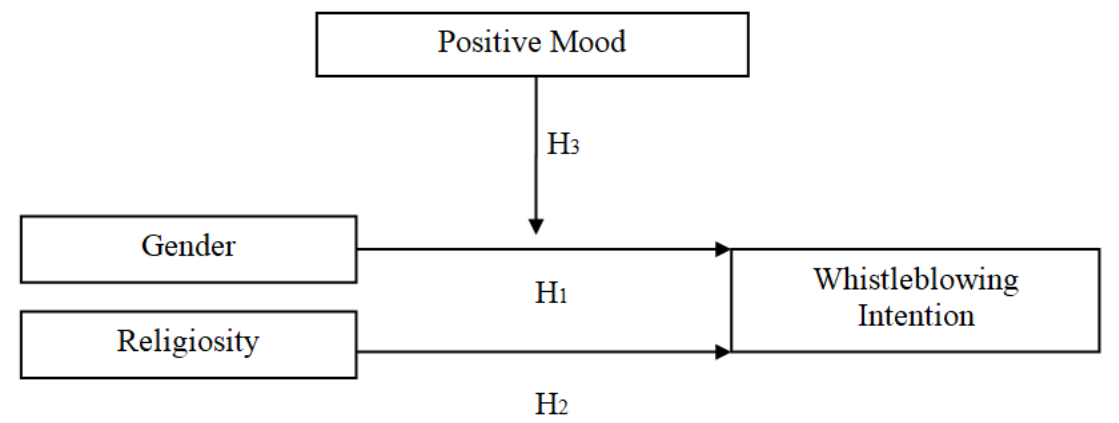

Figure 1 - Research Design (Source: data processed, 2017)

The data source used in this study is the primary data. Primary data collected by using a questionnaire containing a statement and cases distributed to respondents is a master of accounting student university airlangga in 2016 who have been working. Gender and religiosity variables as independent variables in which gender is measured by the dummy scale in which the male is given the number 1 , while the woman is given the number 0 . Religiusity is measured by the Santa Clara Strength of Religious Faith questionnaire or (SCSORF) developed by (Plante \& Boccaccini, 1997). Furthermore, moderation variables were positive mood as measured by The Panas Scale developed by Watson, et al. (1988). Dependent in this research is the intention of whistleblowing which is measured by the indicator adopted from (Malik, 2010), using the Likert scale.

Table 1 - Sample selection process

\begin{tabular}{|c|l|c|}
\hline No & \multicolumn{1}{|c|}{ Information } & Total \\
\hline 1 & Students of accounting master of airlangga university in 2016 & 85 \\
\hline 2 & Students who work & $(44)$ \\
\hline- & Total selected as sample & 41 \\
\hline
\end{tabular}

Source: data processed, 2017.

The equations used in this study are:

$$
W B S=\alpha_{0}+\beta_{1} \operatorname{GENDER}\left(X_{1}\right)+\beta_{2} R L G S\left(X_{2}\right)+\beta_{3} P M\left(X_{3}\right)+\beta_{4} \operatorname{GENDER}{ }^{*} P M\left(X_{1}^{*} X_{3}\right)+\mu
$$

Where: WBS $=$ Whistleblowing Intention; $\alpha=$ Constants; $\beta=$ Regression coefficient; GENDER = Gender; RLGS = Religiosity; $\mu$ = Standard Error.

\section{RESULTS AND DISCUSSION}

The whistleblowing intention variable (WBS) has a minimum value of -14.00 and a maximum value of 20.00 . 
Mean value of 17,170 which means that the average intent of whistleblowing is quite high. The gender variable (GENDER) has a minimum value of 0 , maximum value of 1 and a mean of 0.439 . This mean value of 0.439 indicates that more women than men. The religiosity variable (RLGS) has a minimum value of 32.00 . The maximum indigo is 47.00 and the mean is 39,122 . The mean of 39,122 shows that religiosity is quite high in the respondents. Positive mood (PM) has a minimum value of 43.00 , a maximum value of 79.00 and a mean of 52.634. On average the positive mood of the respondents was not high enough which amounted to 52.634 .

Table 2 - Descriptive Analysis

\begin{tabular}{|c|c|c|c|c|c|}
\hline $\mathrm{n} / \mathrm{n}$ & $\mathrm{N}$ & Minimum & Maximum & Mean & Std. Deviation \\
\hline WBS & 41 & 14,00 & 20,00 & 17,170 & 1,610 \\
\hline GENDER & 41 & 0,00 & 1,00 & 0,439 & 0,502 \\
\hline RLGS & 41 & 32,00 & 47,00 & 39,122 & 2,675 \\
\hline PM & 41 & 43,00 & 79,00 & 52,634 & 6,351 \\
\hline
\end{tabular}

Source: data processed, 2017.

Based on the validity and reliability test that has been done, can be known data in this study is valid and reliable and can be tested continued. Therefore, the available data has been qualified to conduct further test that is correlation test. Correlation test is used to find out how far the relationship between independent variables to the dependent variable can be seen in Table 3 in below:

Table 3 - Correlation Analysis

\begin{tabular}{|c|c|c|}
\hline Variable & Sig.2 tailed & Pearson correlation \\
\hline Gender & 0,000 & 0,646 \\
\hline Religiosity & 0,392 & $-0,137$ \\
\hline Positive Mood & 0,392 & $-0,137$ \\
\hline Gender Positive Mood & 0,000 & 0,635 \\
\hline
\end{tabular}

Source: data processed, 2017.

Based on the above correlation analysis, the Sig.2 Tailed value is $0.00<0.05$. This indicates a significant relationship at the 0.01 level. Then the gender variable $\left(X_{1}\right)$ has a relationship with the whistleblowing intention $(Y)$. These results accept the hypothesis $\mathbf{H}_{1}$ stated gender has a relationship with the intention of whistleblowing. Furthermore, the religiosity variable of Sig. 2 Tailed value is $0,392>0,05$. This shows that there is no significant relationship. Then the religiosity variable $\left(X_{2}\right)$ has no relationship with whistleblowing intention ( $\mathrm{Y}$ ). This result does not accept the hypothesis $\mathbf{H}_{\mathbf{2}}$ which states religiosity has no relationship to whistleblowing intentions.

Result correlation analysis for positive mood variable, Sig.2 Tailed value of $0.392>$ 0.05 . This shows that there is no significant relationship between positive mood variables $\left(X_{3}\right)$ with variable intention of whistleblowing $(Y)$. However, after the interaction with the gender variable $\left(X_{1}\right)$, this positive mood showed a significant result of Sig.2 Tailed 0,00 . These results show that the positive mood variable $\left(X_{3}\right)$ is able to moderate the relationship between gender and whistleblowing intentions. These results accept the hypothesis $\mathbf{H}_{3}$ which states a positive mood moderates the relationship of gender with the intention of whistleblowing.

\section{DISCUSSION OF RESULTS}

Gender and Whistleblowing Intention. The correlation test results show that there is a relationship between gender and whistleblowing intention. These results accept the hypothesis $\mathrm{H}_{1}$ stated gender has a relationship with the intention of whistleblowing, which is where the men gender tend to have a higher whistleblowing intentions. This is because women are less likely than men to engage in whistleblowing because men tend to occupy 
high status positions rather than women within the organization (Dworkin \& Baucus, 1998); (Sims \& Keenan, 1998). Status of characteristic states that those with higher status have more opportunities to contribute to group work, receive more positive evaluations and have more influence (Carli \& Eagly, 1999).

These results support previous studies of Chung \& Trivedi, (2003); Serwinek, (1992) indicates a gender effect on ethical behavior and obedience behavior (eg;whistleblowing). Liyanarachchi \& Newdick, (2009) examined the effect of gender interaction on whistleblowing trends, where the results showed a significant gender effect on the relationship between the level of moral reasoning and whistleblowing tendencies.

Religiosity and Whistleblowing Intention. The result of correlation test proves that there is no relation between religiosity and whistleblowing intention. This result does not accept the hypothesis $\mathrm{H}_{2}$ which states religiosity has no relationship to whistleblowing intentions. This is due to the persecution or persecution of individuals who do whistleblowing and several times the cancellation done by the community related whistleblowing (Dyck et al, 2010). The persistence and persecution of whistleblowing, the whistleblowing intentions will be reduced or even lost even though the individual can be said to be a religious individual. In addition, in the not available of a legal protection against the whistleblower or the whistleblower itself, of course also reduce or eliminate the intention of whistleblowing itself.

Religiosity has no relation to whistleblowing intentions also because of the perception that whistleblowing is also unethical. This argument is supported by Finn \& Lampe's, (1992) research which states that accounting students strongly support whistleblowing as unethical behavior compared to participants who work as auditors. Rokeach, (1969) a religious individual is considered to have a relationship with one's ethical moral improvement. Religious individuals are more obedient to the law and will conduct whistleblowing whenever they are confronted with unethical behavior in the workplace. But a religious person has no connection with whistleblowing intentions because a person is religious but can not apply their moral teachings, nor will their morals change. A person who has no moral improvement has nothing to do with the intention of doing whistleblowing or obeying the rules.

Positive Mood moderate Gender and Whistleblowing Intention. The results of the correlation test proved that the positive mood was able to moderate the relationship between gender and whistleblowing intentions. These results accept the hypothesis $\mathrm{H}_{3}$ which states a positive mood moderates the relationship of gender with the intention of whistleblowing. A men person tends to have higher whistleblowing intentions, that men is in a positive mood will certainly increase the intention of whistleblowing. This is because people with positive mood (PM) may be less concerned about potential risks, and are more likely to be involved in risk taking activities (Bless et al, 1996). Therefore, high positive mood people tend to believe that there is little risk they receive in the event of whistleblowing, and as well as severe retaliation or persecution will not befall them.

George (1991); Van Scotter \& Motowidlo, (1996) people are in the PM (positive mood), they are more likely to help people, protect their organizations, and make constructive suggestions about the organization. Someone who is in a positive mood will take more moral action and empathize, in addition they will also make a moral decision about what is right or wrong. Bandura, (1986) Social Learning Theory argues that one would foresee the possible consequences of their own actions by observing the consequences experienced by others. Positive mood will tend to increase observer's expectation of positive results because people with positive moods may be a little worried. Thus a person in a positive mood will be more likely to be involved in whistleblowing because they will receive less worry about the risks or consequences they will receive.

\section{CONCLUSION}

Based on the analysis and discussion that has been presented, it conclusions as follows: gender related to whistleblowing intentions in accounting master student university airlangga 2016. Our Finding is women are less likely than men to engage in whistleblowing because men tend to occupy high position status than women in an organization, religiosity 
no relation to whistleblowing intentions in accounting master student university airlangga 2016. This is because the act of whistleblowing was also an unethical act, so that someone who is religious is not going to take this action and positive mood moderates the relationship of gender to the intention whistleblowing, this is because people with positive mood may be less concerned about the risks of potential, and more likely to engage in risk-taking activities, one of which is whistleblowing. For further research expected to enhance this research to expand the research area because in this study is only done on the student masters 2016, and then expected to add variables can explain behavioural research in whistleblowing.

\section{REFERENCES}

1. Ajzen, Icek. (1991). The theory of planned behavior. Organizational Behavior and Human Decision Processes. Vol. 50, No. 2, pp. 179-211.

2. Bandura, A. (1986), Social Foundations of Thought and Action, Prentice-Hall, Englewood Cliffs, NJ.

3. Bless, H., Clore, G.L., Schwarz, N., Golisano, V., Rabe, C. \& Wolk, M. (1996), "Mood and the use of scripts: does a happy mood really lead to mindlessness?", Journal of Personality and Social Psychology, Vol. 71, pp. 665-79.

4. Brief, A. P. \& S. J. Motowidlo. (1986). Prosocial Organizational Behaviors. The Academy of Management Review. Vol. 11(4), 710-725.

5. Carli, L. L., \& Eagly, A. H. (1999). Gender effects on social influence and emergent leadership.

6. Chung, J. \& V. U. Trivedy: (2003), The Effect of Friendly Persuasion and Gender on Tax Compliance Behavior, Journal of Business Ethics 47: 133-145.

7. Cunningham \& Harris. (2006). Enron and Arthur Andersen: The Case of the Crooked E and the Fallen A. Global Perspectives on Accounting Education, Vol 3, 27-48.

8. Dozier, J. Brinker \& Marcia P Micelli. (1985). Potential Predictors of Whistleblowing: A Prosocial Behavior Perspective. The Academy of Management Review, Vol.10, No. 4, pp 823-836.

9. Dworkin, T. M., \& Baucus, M. S. (1998). Internal vs. external whistleblowers: A comparison of whistleblowering processes. Journal of Business Ethics, 17(12), 12811298.

10. Dyck, A., Adair, M., \& Zingales, L. (2010). Who blows the whistle on corporate fraud? Journal of Finance, 65, 2213-2254.

11. Eaton, T.V. \& Akers, M.D. (2007), Whistleblowing and good governance, The CPA Journal,Vol. 77 No. 6, pp. 66-71.

12. Fernando, M., \& Jackson, B. (2006). The influence of religion-based workplace spirituality on business leaders' decision-making: An inter-faith study. Journal of Management \& Organization, 12(1), 23-39.

13. Finn, D. W. \& J. C. Lampe. (1992). A study of whistleblowing among auditors. Professional Ethics, 1, 137-168.

14. George, J.M. (1991), "State or trait: effects of positive mood on prosocial behaviors at work", Journal of Applied Psychology, Vol. 76 No. 2, pp. 299-307.

15. Indriantoro, N. \& Supomo, B. (2013). Metodologi Penelitian Bisnis. Yogyakarta: BPFE.

16. Jeon, S. H. (2017) "Where to report wrong doings? Exploring the determinants of internal versus external whistleblowing". International Review of Public Administration, 1-19.

17. Johnson, R. A. (2003). Whistleblowing: When it works and why, Boulder, CO: Lynne Riener Publishers.

18. Lacayo, R. \& A. Ripley: (2002), 'The Whistleblowers, Persons of the Year', Time Magazine 160 (27), 30-60.

19. Malik, R. (2010), Analisis Perbedaan Komitmen Profesional dan Sosialisasi Antisipatif Mahasiswa PPA dan Non-PPA Pada Hubungannya Dengan Whistleblowing (Studi Kasus pada Mahasiswa Akuntansi Universitas Diponegoro). Skripsi. Semarang: Fakultas Ekonomika dan Bisnis, Universitas Diponegoro. 
20. Miceli, M.P., Rehg, M. \& Near, J.P. (1999), “Can laws protect whistle-blowers?”, Work and Occupations, Vol. 26 No. 1, pp. 129-51.

21. Liyanarachchi, G. \& C. Newdick: (2009), The Impact of Moral Reasoning and Reataliation on Whistle Blowing: New Zealand Evindence', Journal of Business Ethics 89:37-57.

22. Plante, T. G., \& Boccaccini, M. T. (1997). The Santa Clara strength of religious faith questionnaire. Pastoral Psychology, 45(5), 375-387.

23. Rest, J. (1986), Moral Development: Advances in Research and Theory, Praeger, New York, NY.

24. Rokeach, M. (1969) Religious Values and Social Comparison, Review of Religious Research. 11 (5), 24-38.

25. Semendawai, A. H., Santoso, F., Wagiman, W., Omas, B. I., \& Susilaningtias, S. M. W. (2011). Memahami Whistleblower. Jakarta: Lembaga Perlindungan Saksi dan Korban (LPSK).

26. Serwinek. P.J., (1992), 'Demographic and Related Differences in Ethical Views Among Small Business', Journal of Business Ethics 11: 555-566, Kluwer Academic Publisher.

27. Sims, R.J. \& Keenan, J.P. (1998), "Predictors of external whistleblowing", Journal of Business Ethics, pp. 411-21.

28. Street, M. D.: (1995), 'Cognitive Moral Development and Organizational Commitment: Two Potential Predicators of Whistle-blowing', Journal of Applied Business Research 11(4), 104-111.

29. Sugiyono, (2013). Metode Penelitian Bisnis. Bandung: Alfabeta.

30. Sweeney, P. (2008) "Hotlines Helpful for Blowing The Whistle". Financial Executive. 24(4), 28-31.

31. Van Scotter, J.R. \& Motowidlo, S.J. (1996), "Interpersonal facilitation and job dedication as separate facets of contextual performance", Journal of Applied Psychology, Vol. 81, pp. 525-31.

32. Watson, D., Clark, L.A. \& Tellegen, A. (1988), "Development and validation of brief measures of positive and negative affect: the PANAS scales", Journal of Personality and Social Psychology, Vol. 54 No. 1, pp. 1063-70.

33. Zhang, J., Chiu, R., \& Wei, L. Q. (2009). On whistleblowing judgment and intention: The roles of positive mood and organizational ethical culture. Journal of Managerial Psychology, 24(7), 627-649. 